\title{
PENGOLAHAN SINGKONG MENJADI TEPUNG MOCAF DAN KERIPIK COMBRO PADA KELOMPOK TANI DESA PUCUNGBEDUG
}

\author{
Cassava Processing into Mocaf Flour and Combro Chips in Pucungbedug Farmers
}

\author{
Fahri Ali ${ }^{1}$, Rennanti Lunnadiyah $\mathrm{A}^{2}$, Rahmat Joko $\mathbf{N}^{3}$ \\ ${ }^{1,2,3}$ Program Studi Agroteknologi, Fakultas Pertanian dan Peternakan, \\ Universitas Ma'arif Nahdlatul Ulama Kebumen, \\ Jl. Kusuma No. 75 Kebumen - Kotak Pos No. 54316 Telp. (0287) 6601209 \\ Email Korespondensi : fahrialiagro@gmail.com
}

\begin{abstract}
ABSTRAK
Produktivitas singkong di Desa Pucungbedug cukup tinggi. Tahun 2014 produkstivitas singkong sebesar 23,86 ton/ha dan meningkat pada tahun 2015 menjadi 26,38 ton/ha. Namun, peningkatan produktivitas singkong tidak diikuti oleh peningkatan pendapatan petani. Hal ini disebabkan karena mereka tidak mempunyai pengetahuan dan juga keahlian tentang pengolahan singkong menjadi produk yang bernilai lebih tinggi. Alternatif pengolahan singkong yang potensial saat ini adalah pengolahan singkong menjadi tepung mocaf dan keripik combro. Metode pelaksanaan dilakukan dalam bentuk penyuluhan, demonstrasi dan pendampingan. Penyuluhan dilakukan dengan cearmah dan diskusi. Bentuk evaluasi berupa daftar pertanyaan yang diberikan sebelum dan sesudah materi penyuluhan disampaikan. Demonstrasi dilaksanakan melalui pelatihan dan praktek. Evaluasi dilakukan terhadap tingkat ketrampilan tentang pembuatan tepung mocaf dan keripik combro kering dengan mengevaluasi pada tahap praktek ditambah dengan penilaian data dari recording yang dilakukan peserta. Pendampingan promosi dan penjualan produk dilakukan dengan membantu membuatkan alat dan media promosi. Evaluasi dilakukan dengan menganalisis keuntungan usaha. Dari kegiatan program kemitraan masyarakat pengolahan singkong menjadi tepung mocaf dan keripik combro pada kelompok tani desa Pucungbedug diperoleh hasil sebagai berikut :

1. Seluruh peserta mengalami peningkatan pengetahuan kewirausahaan dan peluang usaha tentang diversifikasi pengolahan singkong dan secara keseluruhan peningkatan pengetahuan peserta mencapai $36 \%$.

2. Evaluasi terhadap tingkat keterampilan peserta dalam pembuatan tepung mocaf dan keripik combro mendekati kategori baik dengan nilai 3,2.

3. Produk tepung mocaf kurang diterima masyarakat, sedangkan keripik combro dapat diterima masyarakat. Oleh karena itu, usaha pembuatan keripik combro layak untuk dilanjutkan dan dikembangkan.
\end{abstract}

Kata kunci : Ssingkong, Mocaf, Keripik Combro

\section{ABSTRACT}

The productivity of cassava in Pucungbedug Village is quite high. In 2014 cassava productivity was 23.86 tons. $\mathrm{ha}^{-1}$ and increased in 2015 to 26.38 tons. $\mathrm{ha}^{-1}$. But, increasing the productivity of cassava is not followed by an increased in farmers' income. Becaused they have not the knowledge and competence in processing cassava into higher value products. The potential alternative to cassava processing is into modification cassava flour (mocaf) and combro chips. The method of implementation was counseling, demonstration and mentoring. Counseling was carried out with guidance and discussion, and evaluation by pre-test and posttest. Demonstration was carried out with training and practice, and evaluation by skills at the practice and assessment of data recording by participants. Product promotion and sales was by helped to make tools and media promotion. Evaluation was by analyzing business profits. Results showed that :

1. All participants increased in knowledge about diversification of cassava processing and overall increased $36 \%$. 
2. Evaluation the level of skills in making mocaf flour and combro chips near the good category with a value of 3.2 .

3. Mocaf flour products are less accepted by the public, while combro chips are acceptable to the public. Therefore, combro chips manufacturing business deserves to be continued and developed.

Keywords: Cassava, Mocaf, Combro Chips

\section{PENDAHULUAN}

Kondisi tanah di Desa Pucungbedug Kecamatan Purwanegara Kabupaten Banjarnegara tergolong tanah kering dengan sumber air hanya mengandalkan dari air hujan. Tanaman yang banyak dibudidayakan oleh masyarakat di desa ini adalah singkong. Produktivitas singkong di Desa Pucungbedug cukup tinggi. Tahun 2014 produkstivitas singkong sebesar 23,86 ton/ha dan meningkat pada tahun 2015 menjadi 26,38 ton/ha (Badan Pusat Statistik Kabupaten Banjarnegara, 2016). Namun, peningkatan produktivitas singkong tidak diikuti oleh peningkatan pendapatan petani. Hal tersebut disebabkan karena harga jual singkong yang terus menurun. Saat ini harga jual singkong di desa Pucungbedug Rp. 500,-/kg. Oleh karena itu perlu dicari solusi untuk mengatasi murahnya harga singkong tersebut.

Disisi lain, sebagian besar masyarakat di Desa Pucungbedug hanya mengenyam pendidikan sampai Sekolah Dasar, sehingga daya inovasi dan kreativitasnya rendah dalam memanfaatkan sumber daya lokal yang ada. Kegiatan-kegiatan dalam wirausaha di Desa Pucungbedug sangat sedikit. Mata pencaharian utama sebagian besar penduduk adalah petani dan buruh tani sebagai kegiatan turun temurun. Pekerjaan buruh tani dipilih semata-mata karena keterbatasan modal yang dimiliki oleh penduduk setempat dan kepemilikan lahan yang terbatas.
Penghasilan yang belum memadai membuat penduduk Desa Pucungbedug masih mencari pekerjaan lain untuk mencukupi kebutuhan. Untuk membantu mencukupi kebutuhan keluarga, banyak ibu rumah tangga yang bekerja di luar negeri sebagai Tenaga Kerja Wanita (TKW), sedangkan anak-anak yang sudah dewasa bekerja ke luar daerah sebagai buruh bangunan.

Tahun ini sudah terbentuk Kelompok Wanita Tani (KWT) desa Pucungbedug. Dibentuknya KWT ini didasari karena adanya keinginan istri-istri petani untuk meningkatkan kesejahteraan dan ekonomi keluarga. Dengan adanya KWT desa Pucungbedug, para istri memiliki wadah untuk pembelajaran mengenai kegiatan wirausaha. Kelompok Wanita Tani (KWT) merupakan potensi tenaga kerja yang besar yang dapat dimanfaatkan untuk lebih kreatif memanfaatkan potensi sumber daya lokal yang ada sehingga menjadi produktif. Salah satu potensi sumber daya lokal yang tersedia dalam jumlah besar adalah komoditas singkong. Saat ini singkong setelah panen langsung dijual, padahal harganya sangat rendah sehingga petani mengalami kerugian. Hal ini disebabkan karena mereka tidak mempunyai pengetahuan dan juga keahlian tentang pengolahan singkong menjadi produk yang bernilai lebih tinggi. Jika usaha pengolahan singkong menjadi produk yang bernilai lebih tinggi bisa dikembangkan, maka 
nantinya akan bisa meningkatkan perekonomian petani singkong khususnya dan juga masyarakat sekitarnya, karena pembuatan produk olahan ini apabila sudah berkembang dalam skala besar akan lebih banyak membutuhkan tenaga kerja.

Alternatif pengolahan singkong yang sedang digalakkan oleh pemerintah adalah pengolahan singkong menjadi tepung mocaf. Tepung Mocaf (Modified Cassava Flour) dalam bahasa Indonesia disebut Tepung singkong modifikasi, dikatakan sebagai proses modifikasi sebab pada pembuatan mocaf dilakukan proses khusus yang disebut dengan fermentasi atau pereraman yang melibatkan jasa mikrobia atau enzim tertentu, sehingga selama proses fermentasi berlangsung terjadi perubahan yang luar biasa dalam massa ubi baik dari aspek perubahan fisik, kimiawi, dan mikrobiologis serta inderawi. Tanpa pemecahan selulosa, proses pengolahan singkong sekadar menghasilkan tepung gaplek. Aroma singkongnya pun masih menyengat. Dengan fermentasi menggunakan asam laktat tidak hanya didapat mocaf yang bertekstur halus karena selulosa hancur tapi juga aroma singkong hilang dan warna tepung putih.

Beberapa informasi mengatakan bahwa selama proses fermentasi berlangsung tumbuh berbagai spesies mikrobia antara lain Carinebacterium manihot, Geotrichum candidum, Aspergillus sp, Syncephalastrum $s p$, Leuconostop $s p$, Alcaligenus $s p$, Lactobacillus $\quad s p, \quad$ Streptococcus, Aacinotobacter dan Bacillus sp. Semua mikrobia tersebut berperan dalam melakukan perubahan pada massa ubi (Kymaryo et al., 2000).

Mocaf bersifat lebih mudah larut di dalam air, lebih mudah mengembang ketika dipanaskan, tidak beraroma khas ubikayu,

berwarna lebih cerah/putih, dan lebih lunak tekstur produknya dibandingkan dengan tepung ubikayu tanpa fermentasi dan terigu. Dalam pembuatan tepung mocaf diperlukan starter awal untuk proses fermentasi dari singkong yang sudah dikeringkan, dalam hal ini starter yang digunakan adalah berupa produk jadi yang sudah ada dan dijual di pasaran berupa tepung starter Bimo-CF. Starter Bimo-CF diperoleh dengan membeli pada agen penyedia dengan harga yang sangat ekonomis yaitu Rp.50.000 tiap 1 kilogram. Tiap 1 kilogram starter Bimo-CF bisa diaplikasikan pada 1 ton singkong yang sudah dikupas. Perbandingan pendapatan dari harga jual panen singkong, antara hasil panen yang langsung dijual kepada pengepul dalam bentuk umbi asli dengan produk yang sudah diolah sangat berbeda. Harga jual singkong tanpa diolah tiap 1 kilogram saat ini di Desa Pucungbedug hanya Rp. 500,- saja, sedangkan ketika dijual dalam bentuk olahan tepung mocaf bisa mencapai harga minimal Rp. 8000 tiap 1 kilogram.

Hasil olahan singkong lain yang saat ini sedang banyak digemari oleh masyarakat adalah keripik combro. Berbeda dengan keripik singkong yang ada di pasaran, karena keripik combro ini pengolahannya mirip dengan pembuatan kerupuk. Bahan yang digunakan dalam pembuatan keripik combro adalah parutan singkong. Bumbubumbu pembuatannya pun berbeda dengan keripik singkong, karena ada campuran kencur dan cabai rawit dalam resep keripik combro.

Berdasarkan analisis situasi di atas, maka dapat diidentifikasi beberapa permasalahan sebagai berikut :

1. Kelompok tani desa Pucungbedug belum mempunyai pengetahuan kewirausahaan dan peluang usaha 


\section{tentang diversifikasi pengolahan singkong.}

2. Kelompok tani belum memiliki peralatan penunjang untuk diversifikasi pengolahan singkong.

3. Kelompok tani belum memiliki keterampilan dalam diversifikasi pengolahan singkong.

4. Kelompok tani belum mengetahui strategi pemasaran produk.

Dari berbagai permasalahan pada kelompok tani singkong tersebut yang mendapat prioritas untuk dilakukan dalam kegiatan ini adalah:

1. Meningkatan pengetahuan melalui penyuluhan kewirausahaan dan peluang usaha tentang diversifikasi pengolahan singkong.

2. Mengadakan peralatan penunjang untuk diversifikasi pengolahan singkong.

3. Pelatihan dan praktek diversifikasi pengolahan singkong.

4. Pendampingan promosi dan penjualan produk.

\section{METODE}

Kegiatan ini dilakukan bagi kelompok wanita tani Nurul Hikmah dan kelompok tani Ngudi Rejeki desa Pucungbedug. Beberapa tahapan dalam pelaksanaan PKM ini dapat dilihat pada diagram alir sebagai berikut :

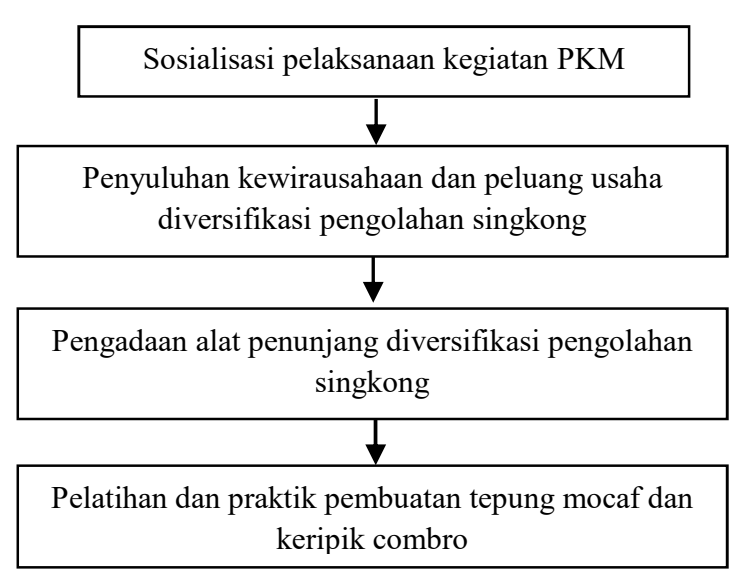

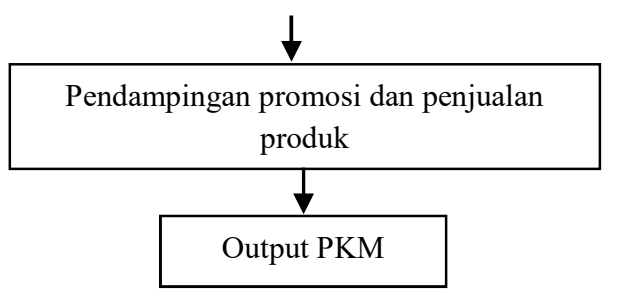

\section{Gambar 1. Diagram Alir Tahapan Pelaksanaan PKM}

\section{a. Sosialisasi Program Kemitraan Masyarakat (PKM)}

Kegiatan ini dilakukan untuk memberitahukan terkait program kemitraan masyarakat (PKM) yang akan pengabdi lakukan di kelompok mitra, yaitu kelompok wanita tani Nurul Hikmah dan kelompok tani Ngudi Rejeki desa Pucungbedug. Output dari kegiatan berupa kesedian dari mitra untuk ikut berpartisipasi dalam kegiatan baik dari sisi waktu, tenaga, dan tempat pelaksanaan.

\section{b. Penyuluhan kewirausahaan dan peluang usaha diversifikasi pengolahan singkong menjadi tepung mocaf dan keripik combro}

Penyuluhan kewirausahaan dan peluang usaha diversifikasi pengolahan singkong dilakukan melalui motode ceramah dan diskusi. Peserta penyuluhan adalah anggota kelompok wanita tani Nurul Hikmah berjumlah 15 orang dan anggota kelompok tani Ngudi Rejeki berjumlah 15 orang, sehingga total peserta berjumlah 30 orang. Kegiatan ini dilaksanakan di gedung Madrasah Ibtidaiyah (MI) Ma'arif Pucungbedug. Alasan pemilihan lokasi penyuluhan tersebut adalah luas dan dekat dengan rumah anggota kelompok tani.

Para peserta diberikan materi secara tertulis (dalam bentuk makalah) yang dibagikan. Materi yang disampaikan berupa pengolahan singkong menjadi tepung mocaf dan keripik combro, teknis

Fahri A, Rennanti L.A, Rahmat J.N., PENGOLAHAN SINGKONG MENJADI... 47 
penggunaan mesin penggilingan tepung, mesin parut dan alat perekat plastik (impulse sealer). Pengolahan singkong menjadi tepung mocaf menggunakan teknologi starter BIMO-CF. Permasalahan yang disampaikan dalam teknis penggunaan mesin diantaranya cara pengoperasisan, perawatan mesin dan cara menjaga keselamatan dan kesehatan kerja (K3) dalam menggunakan mesin penggilingan tepung, mesin parut dan alat perekat plastik (impulse sealer).

Bentuk evaluasi berupa daftar pertanyaan yang diberikan sebelum dan sesudah materi penyuluhan disampaikan. Soal dalam daftar pertanyaan disusun untuk mengetahui seberapa besar tingkat pemahaman peserta terhadap teknologi pembuatan tepung mocaf dan keripik combro serta aplikasinya. Jawaban dari setiap soal berupa pilihan ganda dengan memilih salah satu jawaban yang paling tepat. Nilai dihitung menggunakan rumus:

Nilai peserta $=$ (jumlah jawaban betul) $/$ (jumlah soal) x 100 .

Nilai akhir $=$ rataan nilai seluruh peserta.

Nilai peserta kegiatan adalah rerata skor seluruh jawaban. Nilai keseluruhan adalah rerata nilai seluruh peserta kegiatan. Selisih nilai akhir dari yang diberikan sebelum dan sesudah materi penyuluhan merupakan peningkatan tingkat pemahaman peserta.

\section{c. Mengadakan peralatan penunjang untuk diversifikasi pengolahan singkong}

Berdasarkan pada tujuan program PKM ini maka kegiatan yang akan dilakukan berupa pelatihan ketrampilan pengolahan singkong menjadi tepung mocaf dan keripik combro. Maka langkah yang dilakukan yaitu berupa pengadaan alat untuk membuat tepung mocaf yaitu mesin penggilingan tepung. Sedangkan pengadaan alat untuk membuat keripik combro yaitu mesin parut. Alat lain yang dibutuhkan untuk mengemas produk adalah alat perekat plastik (impulse sealer).

\section{d. Pelatihan dan praktek pengolahan singkong menjadi tepung mocaf dan keripik combro}

Kegiatan ini menggunakan metode demonstrasi. Metode demonstrasi diperlukan untuk memberi pengetahuan, pengalaman, pemahaman, dan contoh kepada kelompok wanita tani Nurul Hikmah dan kelompok tani Ngudi Rejeki desa Pucungbedug. Penggunaan metode demonstrasi ini untuk memberikan contoh praktis dalam hal pembuatan tepung mocaf dan keripik combro, teknik mengoperasikan mesin penggilingan tepung, mesin parut dan alat perekat plastik (impulse sealer) dan cara menjaga keselamatan dan kesehatan kerja. Keselamatan dan kesehatan kerja dapat ditinjau dari keamanan mesin yang digunakan, orang yang bekerja, maupun makanan yang akan dihasilkan.

Pelatihan diberikan kepada para anggota kelompok yang berjumlah sekitar 30 orang dan dibagi dalam 2 kelompok masingmasing 15 orang. Materi pelatihan meliputi cara pembuatan tepung mocaf (menggunakan starter BIMO-CF) dan keripik combro. Pelatihan diberikan secara demonstrasi dengan menyertakan keterlibatan aktif semua peserta pelatihan.

Evaluasi terhadap tingkat ketrampilan tentang pembuatan tepung mocaf dan keripik combro dilakukan dengan mengevaluasi pada tahap praktek ditambah dengan penilaian data dari recording yang dilakukan peserta, dengan tata penilaian seperti pada Tabel 1 dan 2 . 
Tabel 1. Format Penilaian Kemampuan Praktek Pembuatan Tepung Mocaf dan Pencatatannya

\begin{tabular}{|l|l|l|l|l|}
\hline No & \multicolumn{1}{|c|}{ Butir } & Bobot & Skor & Nilai \\
\hline 1 & $\begin{array}{l}\text { Persiapan } \\
\text { peralatan dan } \\
\text { bahan }\end{array}$ & $10 \%$ & & \\
\hline 2 & $\begin{array}{l}\text { Pengupasan, } \\
\text { pencucian dan } \\
\text { penyawutan }\end{array}$ & $25 \%$ & & \\
\hline 3 & $\begin{array}{l}\text { Fermentasi dan } \\
\text { penirisan }\end{array}$ & $25 \%$ & & \\
\hline 4 & $\begin{array}{l}\text { Pengeringan dan } \\
\text { penggilingan }\end{array}$ & $25 \%$ & & \\
\hline 5 & $\begin{array}{l}\text { Kualitas tepung } \\
\text { mocaf yo yang } \\
\text { dihasilkan }\end{array}$ & \multicolumn{5}{|c|}{ Jumlah Nilai } & \\
\hline \multicolumn{5}{|c|}{ kurang, 4= baik dan 5= sangat baik) } \\
Catatan: Skor = 1, 2, 4 atau 5 (1= sangat kurang, 2= \\
Nilai = Skor x Bobot.
\end{tabular}

Tabel 2. Format Penilaian Kemampuan Praktek Pembuatan Keripik Combro dan Pencatatannya

\begin{tabular}{|l|l|l|l|l|}
\hline No & \multicolumn{1}{|c|}{ Butir } & Bobot & Skor & Nilai \\
\hline 1 & $\begin{array}{l}\text { Persiapan } \\
\text { peralatan dan } \\
\text { bahan }\end{array}$ & $10 \%$ & & \\
\hline 2 & $\begin{array}{l}\text { Pengupasan, } \\
\text { pencucian dan } \\
\text { pemarutan }\end{array}$ & $25 \%$ & & \\
\hline 3 & $\begin{array}{l}\text { Pengepresan dan } \\
\text { pencampuran } \\
\text { adonan }\end{array}$ \\
\hline 4 & $\begin{array}{l}\text { Pencetakan dan } \\
\text { penggorengan }\end{array}$ & $25 \%$ & & \\
\hline 5 & $\begin{array}{l}\text { Kualitas keripik } \\
\text { yang dihasilkan }\end{array}$ & $15 \%$ & & \\
\hline \multicolumn{4}{|c|}{ Jumlah Nilai } & \\
\hline Catatan : Skor = 1, 2, 4 atau 5 (1= sangat kurang, 2= \\
kurang, 4= baik dan 5= sangat baik
\end{tabular}

e. Pendampingan promosi dan penjualan produk

Kegiatan pendampingan dalam rangka menunjang promosi dan penjualan produk antara lain:

1) Pendampingan pengurusan pengajuan ijin P.IRT ke Dinkes Banjarnegara. Tim PKM membantu melengkapi syarat- syarat yang dibutuhkan dalam pengajuan ijin P.IRT.

2) Membantu menfasilitasi beberapa kerjasama, antara lain dengan Dinas UMKM, UMKM dan toko oleh-oleh khas daerah.

3) Membantu membuat media on-line seperti facebook, twitter, instagram dan blog untuk promosi dan pemasaran produk.

4) Membantu mengikutkan dalam acara Bazar/Expo produk-produk UMKM.

Bentuk evaluasi dalam kegiatan ini adalah analisis keuntungan usaha. Kegiatan ini berhasil apabila kelompok tani memperoleh keuntungan dari usaha pembuatan tepung mocaf dan keripik combro yang dilakukan.

\section{HASIL DAN PEMBAHASAN}

Kegiatan diikuti sekitar 30 orang anggota Kelompok Tani. Sebelum acara dimulai kepada para peserta diberikan sejumlah pertanyaan (pre-test), demikian pula ketika acara berakhir (post-test). Hal ini digunakan untuk mengevaluasi keberhasilan kegiatan. Hasil evaluasi peningkatan pengetahuan para peserta yang didasarkan pada pre-test dan post-test disajikan pada Gambar 2.

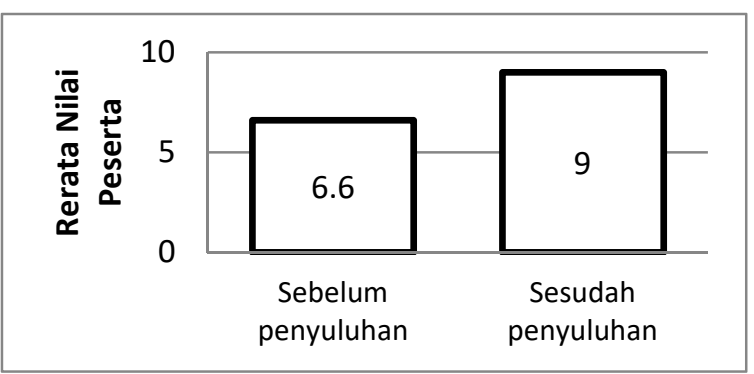

Gambar 2. Hasil Evaluasi Peningkatan Pengetahuan Peserta Penyuluhan

Hasil evaluasi menunjukkan bahwa terjadi peningkatan pengetahuan peserta dari kegiatan penyuluhan sebesar 36\%. 
Besarnya peningkatan pengetahuan ini menunjukkan bahwa terdapat perbedaan yang nyata terhadap pengetahuan peserta sebelum penyuluhan dan setelah penyuluhan.

Setelah pelaksanaan pemberian teori tentang tepung mocaf dan keripik combro, dilanjutkan dengan praktek pembuatan tepung mocaf dan keripik combro. Evaluasi keterampilan peserta dalam pembuatan tepung mocaf dilakukan dengan cara mengamati keterampilan peserta mulai dari kegiatan persiapan alat dan bahan, pengupasan, pencucian dan penyawutan, fermentasi dan penirisan, pengeringan dan penggilingan serta penilaian kualitas tepung mocaf yang dihasilkan. Hasil evaluasi keterampilan peserta dalam pembuatan tepung mocaf menunjukkan kategori mendekati baik dengan nilai 3,2.

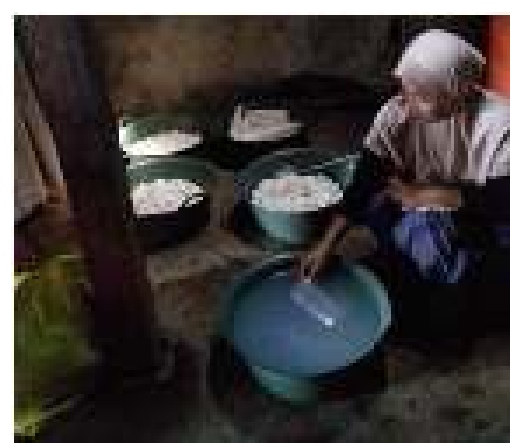

\section{Gambar 3. $\quad$ Fermentasi Singkong Menggunakan Starter BIMO-CF}

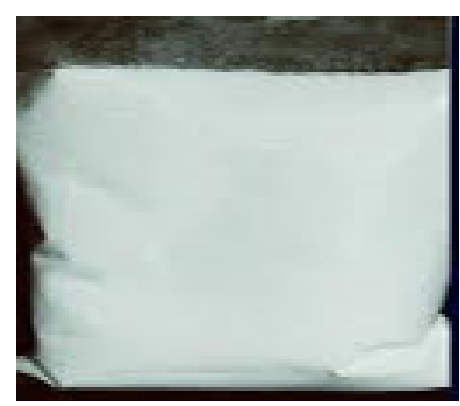

Gambar 4. Tepung Mocaf Hasil Praktek

Evaluasi dalam pembuatan keripik combro dilakukan dengan cara mengamati keterampilan peserta mulai dari kegiatan persiapan alat dan bahan, pengupasan pencucian dan pemarutan, pengepresan dan pencampuran adonan, pencetakan dan penggorengan serta penilaian kualitas keripik combro yang dihasilkan. Hasil evaluasi keterampilan peserta dalam pembuatan keripik combro menunjukkan kategori mendekati baik dengan nilai 3,2.

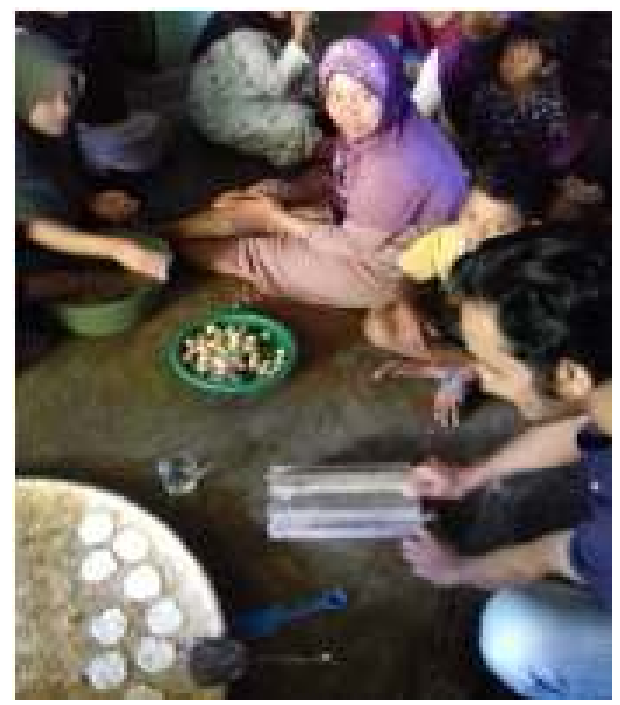

Gambar 5. Proses Pencetakan Keripik Combro

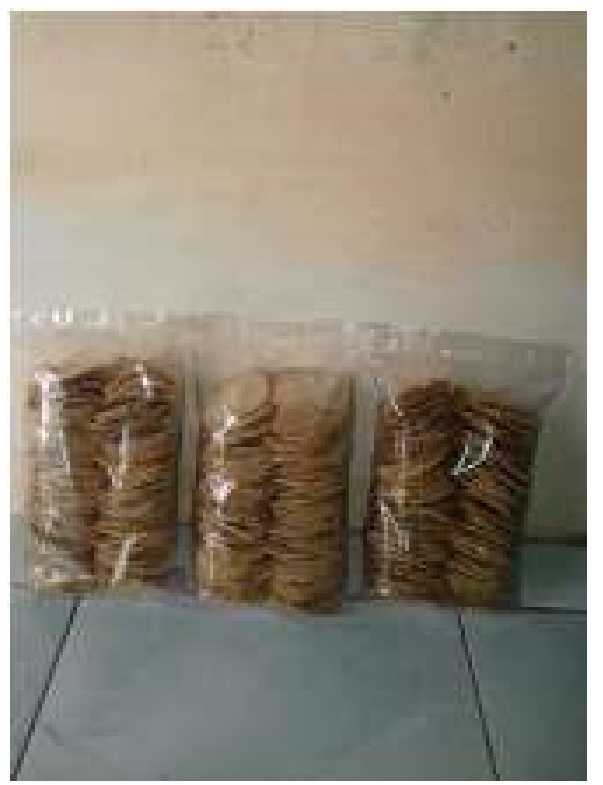

Gambar 6. Keripik Combro Hasil Praktek

Pemasaran tepung mocaf dan keripik combro dilakukan dengan cara dititipkan ke toko-toko sembako. Berdasarkan hasil 
evaluasi pemasaran, produk tepung mocaf kurang laku di pasaran. Hal tersebut disebabkan karena masyarakat belum mengenal, sehingga lebih memilih tepung terigu.

Hasil evaluasi pemasaran produk keripik combro dapat diterima oleh masyarakat. Hal tersebut dapat dilihat dari banyaknya permintaan pemesanan keripik combro oleh toko-toko sembako. Berdasarkan hasil analisis usaha pembuatan keripik combro, keuntungan yang diperoleh dapat mencapai $100 \%$. Oleh karena itu, usaha pembuatan keripik combro layak untuk dilanjutkan dan dikembangkan.

\section{PENUTUP}

Dari kegiatan program kemitraan masyarakat pengolahan singkong menjadi tepung mocaf dan keripik combro pada kelompok tani desa Pucungbedug dapat disimpulkan sebagai berikut:

1. Seluruh peserta mengalami peningkatan pengetahuan kewirausahaan dan peluang usaha tentang diversifikasi pengolahan singkong dan secara keseluruhan peningkatan pengetahuan peserta mencapai $36 \%$.

2. Evaluasi terhadap tingkat keterampilan peserta dalam pembuatan tepung mocaf dan keripik combro mendekati kategori baik dengan nilai 3,2 .

3. Produk tepung mocaf kurang diterima masyarakat, sedangkan keripik combro dapat diterima masyarakat. Oleh karena itu, usaha pembuatan keripik combro layak untuk dilanjutkan dan dikembangkan.

\section{UCAPAN TERIMAKASIH}

Ucapan terima kasih disampaikan kepada pihak-pihak yang telah membantu dalam penelitian ini, antara lain : DRPM Ditjen Penguatan Risbang Kemristekdikti, Kopertis Wilayah VI Jawa Tengah dan LPPM UMNU Kebumen.

\section{DAFTAR RUJUKAN}

Badan Pusat Statistik Kabupaten Banjarnegara (2016). Statistik Daerah Kecamatan Purwanegara 2016 (p. 13). Banjarnegara: BPS Kabupaten Banjarnegara.

Kimaryo, V.M., G.A, Massawe, N.A, Olasupo, \& W.H, Holzapfel (2000). The use of a starter culture in the fermentation of cassava for the production of "kivunde", a traditional Tanzanian food product. International Journal of Food Microbiology, 56(23), 179-190. 